\title{
Hubungan Pola Asuh Orang Tua Tunggal Ibu dengan kematangan Emosi dan Keterampilan Sosial pada Anak Pra Sekolah usia 4-6 tahun di PAUD Kecamatan Koto Tangah Kota Padang Tahun 2019
}

Helni Anggraini ${ }^{1}$, Arni Amir², Yantri Maputra ${ }^{3}$

Abstrak

Pola asuh orang tua tunggal ibu merupakan perilaku dan sikap ibu dalam pengasuhan anak yang berefek terhadap perkembangan dan kesejahteraan anak baik dalam keluarga maupun dilingkungan sekolah. Keberhasilan orang tua tunggal ibu dalam menjalankan perannya dapat dilihat dari tingkah laku anak dalam mengekspresikan emosi dan sosial anak. Tujuan: Mengetahui hubungan pola asuh orang tua tunggal ibu dengan kematangan emosi dan keterampilan sosial anak pra sekolah usia 4-6 tahun. Metode: Penelitian ini merupakan studi analitik menggunakan desain cross sectional dengan jumlah 40 orang responden dengan teknik cluster sampling. Pengumpulan data dilakukan melalui wawancara langsung dengan responden, pada variabel pola asuh menggunakan Parental Authority Quetionare (PAQ), kematangan emosi menggunakan kuesioner yang dirancang peneliti, dan keterampilan sosial menggunakan Vineland Social Maturity Scale (VSMS) penelitian dilakukan di Pendidikan Anak Usia Dini (PAUD) Kecamatan Koto Tangah Kota Padang pada bulan Maret-Juni 2019. Analisis data menggunakan uji Chi-square. Hasil: Sebagian besar pola asuh yang banyak diterapkan oleh orang tua tunggal ibu yaitu pola asuh demokratif $(87,5 \%)$, lebih dari separoh kematangan emosi tinggi (70\%), sebagian besar keterampilan sosial rendah (87,5\%). Terdapat hubungan pola asuh orang tua tunggal ibu dengan kematangan emosi $\boldsymbol{\rho}=0,002$ dan terdapat hubungan pola asuh dengan keterampilan sosial $\rho=0,014$. Simpulan: Terdapat hubungan pola asuh orang tua tunggal ibu dengan kematangan emosi dan keterampilan sosial anak pra sekolah usia 4-6 tahun.

Kata kunci: pola asuh, orang tua tunggal ibu, kematangan emosi, keterampilan sosial

\section{Abstract}

The pattern of single mothers parenting is the behavior and attitudes of mothers in childcare that affect the development and welfare of children both of the family and the school environment. The success of single-parent mothers in their role can be seen from the behavior of children in expressing emotions and social development. Objectives: To determined the relationship of single-mother parenting on emotional maturity and social skills of preschool children aged 4-6 years old. Methods: This was an analytic study using cross-sectional design with forty of respondents to the cluster sampling technique. Data collection was conducted through direct interviews with respondents, the parenting style variable by using the Parental Authority parenting Questionaire (PAQ), emotional maturity using questionnaires designed researcher, and social skills using the Vineland Social Maturity Scale (VSMS) conducted research in early childhood Tangah Koto District of Padang in from March until June in 2019. Data analyzed by using Chi-square test. Results: The most parenting widely adopted by single-parent mothers are parenting democratic (87.5\%), more than half of high emotional maturity (70\%), most of the low social skills (87.5\%), There are relationships between parenting single-parent mothers with emotional maturity $\rho$ value of 0.002 and relationships parenting style with social skills parenting $\rho$ value of 0.014. Conclusion: There is significant relationship between single-mother parenting on emotional maturity and social skills of pre-school children aged 4-6 years old.

Keywords: parenting, single parents mother, emotional maturity, social skills 
Affiliasi penulis: 1. Prodi Magister IImu Kebidanan Fakultas Kedokteran Universitas Andalas Padang (FK Unand), 2. Bagian Biologi FK Unand, 3. Prodi Psikologi Fakultas Kedokteran Universitas Andalas.

Korespondensi: Arni Amir, amir_arni@yahoo.com Telp: 085263371110

\section{PENDAHULUAN}

Perceraian dapat merubah struktur keluarga menjadi tidak lengkap dengan hilangnya salah satu figur orang tua. Perceraian dapat mengganggu pengasuhan anak karena orang tua kesulitan untuk memantau dan mengawasi anak-anak dalam menerapkan displin serta berkuranganya kasih sayang orang tua. Perceraian dapat meningkatkan depresi, kecemasan dan stress sehingga menurunkan kemampuan orang tua untuk menjadi orang tua yang baik dalam keluarga. ${ }^{1}$

Keterlibatan orang tua dalam proses pendidikan anak sangat dibutuhkan karena peranan orang tua berpengaruh pada prestasi anak di sekolah. ${ }^{2}$ Idealnya pola pengasuhan anak dilakukan oleh kedua orang tua, namun tidak selalu dapat dipertahankan karena kematian dan perceraian menyebabkan munculnya keluarga single parent/orang tua tunggal. ${ }^{3}$

Pengasuhan yang diterapkan oleh orang tua tunggal ibu tidak sama dengan orang tua utuh. Orang tua tunggal ibu menjalankan kehidupan berkeluarga tanpa pasangan, sehingga harus mandiri dalam menjalankan fungsi dan perannya. Keberhasilan orang tua tunggal ibu dalam menjalankan peran mengasuh anak dapat dilihat dari bagaimana anak tersebut bertingkah laku dalam mengekspresikan emosinya dan bersosialisasi. ${ }^{4}$

Kematangan emosi merupakan komponen penting pada kepribadian yang mencirikan sifat seseorang. Kematangan emosi pada anak dapat mengembangkan keterampilan sosial anak diantaranya menjalin interaksi dengan lingkungan sosial, untuk mengenali perasaan sendiri, untuk beradaptasi pada sikon yang berbeda, mengendalikan emosi, reaksi dan perilaku sendiri. ${ }^{5}$

Keterampilan sosial merupakan kemampuan individu dalam berinteraksi dengan orang disekitar agar dapat diterima oleh teman sebaya, mendapatkan rasa dibutuhkan dan rasa berharga. Keterampilan sosial membina dan menanggapi hubungan antar pribadi dgn anak lain secara memuaskan. ${ }^{6}$ Prevalensi keluarga dengan orang tua tunggal meningkat secara substansial dari tahun 1970 sampai sekarang, sekitar $30 \%$ anak-anak sekarang hidup dengan satu orang tua/orang tua tungal, di Amerika Serikat mayoritas keluarga (83\%) di pimpin oleh seorang ibu. ${ }^{7}$

lbu lebih sering menjadi orang tunggal dibanding ayah karena ibu lebih banyak waktu dalam pengasuhan anak dan pekerjaan rumah dibanding ayah. Namun pada ibu yang bekerja mempunyai waktu yang lebih sedikit dalam tugas rumah tangga dan berhubungan dengan anak, hal ini tanpa diimbangi dengan keikutsertaan ayah di rumah. ${ }^{8}$

Selama beberapa tahun terakhir kasus perceraian menjadi fenomena dunia, pada tahun 2012 perceraian di dunia mencapai 5.685 .602 kasus. Negara yang memiliki kasus perceraian terbanyak adalah Cina yaitu 2.111.000 pada tahun 2011 Amerika Serikat dengan 8.777.000 kasus, Rusia dengan 669.376 kasus, selanjutnya Jepang dengan 235.719 kasus perceraian. ${ }^{9}$

Provinsi Sumatera Barat berada di urutan ke13 dengan jumlah kasus perceraian sebanyak 6.216 kasus perceraian (BPS Indonesia 2016). Pada tahun 2013 kota Padang memiliki kasus perceraian sebanyak 1.035 kasus perceraian, tahun 2014 sebanyak 1.104 kasus perceraian, tahun 2015 sebanyak 1.246 kasus perceraian dan tahun 2016 sebanyak 1.292 kasus perceraian, tiap tahunnya angka perceraian selalu meningkat. Angka perceraian tertinggi di Kota Padang terdapat di Kecamatan Koto Tangah dengan penyebab terbanyak yaitu perselisihan dalam rumah tangga dan meninggalkan kewajiban. ${ }^{10}$

Hasil survei pendahuluan yang telah dilakukan di berbagai PAUD di Kecamatan Koto Tangah Kota Padang yang terdiri dari 15 orang tua tunggal yang memiliki anak usia 5-6 tahun, didapatkan 6 anak ( $40 \%$ ) dengan kematangan emosi tinggi, sedangkan 9 anak $(60 \%)$ dengan kematangan emosi rendah. Uji keterampilan sosial pada responden yang didapatkan 4 anak (26.7\%) dengan keterampilan sosial tinggi dan 11 anak $(73,3 \%)$ dengan kerampilan sosial rendah.

Berdasarkan latar belakang diatas pola asuh orang tua tunggal ibu dapat mempengaruhi perilaku 
anak sehari-hari, sehingga penulis tertarik untuk melakukan penelitian tentang Pola Asuh Orang Tua Tunggal ibu dengan Kematangan Emosi dan Keteranpilan Sosial Pada Anak Pra Sekolah di PAUD Kecamatan Koto Tangah Kota Padang.

\section{METODE}

Penelitian ini merupakan studi analitik dengan desain atau pendekatan cross sectional. Penelitian ini dilakukan di IPendidikan Anak Usia Dini (PAUD) yang ada di Kecamatan Koto Tangah Kota Padang untuk mengetahui hubungan pola asuh orang tua tunggal ibu dengan kematangan emosi dan keterampilan sosial pada anak pra sekolah usia 4-6 tahun.

Penelitian dilakukan dengan metode wawancara langsung dengan lembar kuesioner sebagai acuan pada bulan Maret sampai Mei 2019. Populasi penelitian adalah orang tuanggal ibu yang memiliki anak usia pra sekolah 4-6 tahun di PAUD Kecamatan Koto Tangah Kota Padang. Subjek penelitian yang memenuhi kriteria inklusi, dengan tekhnik pengambilan sampel secara cluster sampling yaitu sampel diambil dari kelompok-kelompok unit yang kecil.

Kriteria inklusi pada penelitian ini adalah orang tua tunggal ibu yang bersedia manjadi responden dalam penelitian dan menandatangani lembar persetujuan penelitian (informed consent).

Variabel yang diteliti dalam penelitian dibagi dua kelompok yaitu variabel terikat dan variabel bebas. Variabel terikat adalah kematangan emsosi dan keterampilan sosial dan varibael bebas adalah pola asuh orang tua tunggal ibu.

Analisis univariat untuk melihat distribusi frekuensi pola asuh orang tua tunggal ibu, kematangan emosi dan keterampilan sosial. Analisis bivariat menggunakan uji Chi-square untuk mengetahui hubungan anatara variabel independen dengan dependen. Hasil analisis dianggap bermakna bila didapat $p<0,05$.

\section{HASIL}

Hasil penelitian terhadap 40 responden didapat karakteristik responden.
Tabel 1. Karakteristik responden

\begin{tabular}{lcc}
\hline Karakteristik responden & $\mathbf{f}$ & $\%$ \\
\hline Usia lbu & 1 & 2.5 \\
$17-25$ & 25 & 62.5 \\
$26-35$ & 14 & 35 \\
$36-45$ & & \\
Tingkat pendidikan ibu & 3 & 7,5 \\
SD & 5 & 12,5 \\
SMP & 20 & 50 \\
SMA & 12 & 30 \\
PT & & \\
Pekerjaan & 25 & 62,5 \\
Bekerja & 15 & 37,5 \\
IRT & & \\
Urutan anak & & 7,5 \\
Sulung & 3 & 15 \\
Tengah & 6 & 52,5 \\
Bungsu & 21 & 25 \\
Tunggal & 10 & \\
\hline & & \\
\hline & &
\end{tabular}

Hasil dari Tabel 1 menunjukkan berdasarkan kelompok umur ibu lebih dari separoh (62,5\%) pada usia 26-35 tahun. Berdasarkan tingkat pendidikan tertinggi separohnya (50\%) pendidikan SMA, bedasarkana status pekerjaan ibu lebih dari separoh $(62,5 \%)$ ibu bekerja, berdasarkan urutan kelahiran anak lebih dari separoh (52,5\%) anak bungsu,

\section{ANALISIS UNIVARIAT}

Analisis univariat dilakukan untuk melihat distribusi frekuensi variabel independen (pola asuh orang tua tunggal ibu) dan dependen (kematangan emosi dan keterampilan sosial).

Tabel 2. Distribusi frekuensi pola asuh orang tua tunggal ibu

\begin{tabular}{ccc}
\hline Tipe pola asuh & $\mathbf{f}$ & $\%$ \\
\hline Demokratis & 35 & 87,5 \\
Otoriter & 2 & 5 \\
Permisif & 3 & 7,5 \\
\hline Jumlah & 40 & 100 \\
\hline
\end{tabular}

Hasil dari Tabel 2 menunjukkan bahwa sebagian besar $(87,5 \%)$ pada tipe pola asuh demokratif. 
Tabel 3. Distribusi frekuensi kematangan emosi anak pra sekolah usia 4-6 tahun

\begin{tabular}{ccc}
\hline Kematangan emosi & $\mathbf{f}$ & $\%$ \\
\hline Rendah & 12 & 30 \\
Tinggi & 28 & 70 \\
\hline Jumlah & 40 & 100 \\
\hline
\end{tabular}

Hasil dari Tabel 3 menunjukkan bahwa sebagian besar (70\%) dengan kematangan emosi tinggi.

Tabel 4. Distribusi frekuensi keterampilan sosial anak pra sekolah usia 4-6 tahun

\begin{tabular}{crc}
\hline Keterampilan sosial & $\mathbf{f}$ & $\%$ \\
\hline Rendah & 35 & 87,5 \\
Tinggi & 5 & 12,5 \\
\hline Jumlah & 40 & 100 \\
\hline
\end{tabular}

Hasil dari Tabel 4 menunjukkan bahwa sebagaian besar $(87,5 \%)$ dengan keterampilan sosial rendah.

\section{ANALISIS BIVARIAT}

Analisis bivariat dilakukan untuk melihat hubungan anatara variabel independen (pola asuh orang tua tunggal ibu) dengan variabel dependen (kematangan emosi dan keterampilan sosial) dengan menggunakan uji Chi-square. Hasil analisis dianggap bermakna bila nilai $p<0,05$. Berikut hasil analisis bivariat pola asuh orang tua tunggal ibu dengan kematangan emosi dan keterampilan sosial pada anak pra sekolah usia 4-6 tahun.

Tabel 5. Hubungan pola asuh orang tua tunggal ibu dengan kematangan emosi anak pra sekolah usia 4-6 tahun

\begin{tabular}{|c|c|c|c|c|c|}
\hline \multirow{3}{*}{$\begin{array}{l}\text { Tipe pola } \\
\text { asuh }\end{array}$} & \multicolumn{4}{|c|}{ Kematangan emosi } & \multirow{3}{*}{$\rho$} \\
\hline & \multicolumn{2}{|c|}{ Rendah } & \multicolumn{2}{|c|}{ Tinggi } & \\
\hline & $f$ & $\%$ & $f$ & $\%$ & \\
\hline Demokratif & 7 & 20 & 28 & 80 & \\
\hline Otoriter & 2 & 100 & 0 & 0 & 0,002 \\
\hline Permisif & 3 & 100 & 0 & 0 & \\
\hline
\end{tabular}

Hasil dari Tabel 5 menunjukkan persentase kematangan emosi tinggi, paling tinggi pada pola asuh demokratif yaitu (80\%). Hasil uji Chi-square ada nilai expected kurang dari 5 maka dilanjutkan dengan uji Kruskal-Wallis didapat $\rho<0,05$ artinya terdapat hubungan yang bermakna antara pola asuh dengan kematangan emosi pada anak pra sekolah usis 4-6 tahun.

Tabel 6. Hubungan pola asuh orang tua tunggal ibu dengan kematangan emosi anak pra sekolah usia 4-6 tahun

\begin{tabular}{crrrrr}
\hline & \multicolumn{4}{c}{ Keterampilan sosial } & \\
\cline { 2 - 4 } Tipe pola asuh & \multicolumn{2}{c}{ Rendah } & \multicolumn{2}{c}{ Tinggi } & $\boldsymbol{\rho}$ \\
& $\mathbf{f}$ & $\%$ & $\mathbf{f}$ & $\%$ & \\
\hline Demokratif & 32 & 91,4 & 3 & 8,6 & \\
Otoriter & 2 & 100 & 0 & 0 & 0,014 \\
Permisif & 1 & 33,3 & 2 & 66,7 & \\
\hline Jumlah & 35 & 87.5 & 5 & 12.5 & \\
\hline
\end{tabular}

Hasil dari Tabel 6 menunjukkan persentase keterampilan sosial rendah, paling tinggi pada pola asuh demokratif yaitu 91,4\%. Hasil uji Chi-square ada nilai expected kurang dari 5 maka dilanjutkan dengan uji Kruskal-Wallis didapat $\rho<0,05$ artinya terdapat hubungan yang bermakna antara pola asuh dengan keterampilan sosial pada anak pra sekolah usis 4-6 tahun.

\section{PEMBAHASAN}

\section{Pola asuh orang tua tunggal ibu}

Hasil penelitian menunjukkan bahwa pola asuh orang tunggal ibu yang banyak diterapkan dalam keluarga adalah pola asuh demokratif sebanyak 35 responden (87,5\%), dibanding dengan pola asuh otoriter 2 responden (5\%) dan permisif 3 responden $(7,7 \%)$ orang. Sebagian besar orang tua tunggal ibu dalam keluarga menerapkan pola asuh demokratis, pola pengasuhan ini ibu menghargai individualitas anak namun ada batasan-batasannya.

Pada umumnya orang tua tunggal ibu mempunyai keyakinan, kemampuan dan peraturanperaturan yang diterapkan dalam keluarga namun pada tipe demokratis ini ibu menghormati pendapat, keputusan, ketertarikan, kepribadian anak dan menuntut perilaku yang baik. Pada tipe ini ibu juga akan memberikan hukuman yang bijaksana dan terbatas ketika hal tersebut dibutuhkan dalam konteks hubungan yang hangat dan suportif. ${ }^{11}$ 
Pola asuh orang tua bersifat multidimensi, orang tua harus mengembangkan pengetahuan, mulai dari menyadari perkembangan dan norma-norma yang membantu dalam menjaga keamanan, kesehatan dan sosial yang berinteraksi dengan keluarga serta mendukung gaya pengasuhan. Orang tua dengan tingkat pendidikan yang lebih tinggi cendrung lebih bannyak tahu tentang proses perkembangan anak dan strategi pengasuhan yang efektif. ${ }^{12}$

\section{Kematangan emosi}

Hasil penelitian diketahui bahwa sebanyak 28 anak (70\%) dengan kematangan emosi tinggi dan kematangan emosi rendah sebanyak 12 anak (30\%). Pola asuh yang diterapkan oleh ibu tunggal dalam keluarga akan mempengaruhi kematangan emosi pada anak. Kematangan emosi tinggi pada anak karena kedekatan ibu dan anak sehingga mengajarkan anak untuk bersabar,berjiwa besar, peduli dan saling memaafkan

Ibu dan anak yang menghabiskan waktu bersama dalam kegiatan pendidikan seperti menggambar, membaca, melukis, atau bermain menunjukkan kematangan emosional positif pada anak, kedekatan ibu dan anak akan menggambarkan gaya pengasuhan yang diterapkan oleh ibu. ${ }^{13}$

\section{Keterampilan sosial}

Hasil penelitian menunjukkan bahwa sebanyak $35(87,5 \%)$ anak dengan keterampilan sosial rendah. Banyak anak dalam keluarga yang selalu didampingi oleh ibu seperti mau tidur di dampingi ibunya, mandi masih dibantu oleh ibu, sebagian ibu tidak mengajarkan anak untuk mengetahui mata uang karena si ibu tidak mau anak selalu meminta uang.

Keterampilan sosial merupakan kemampuan anak dalam berinteraksi sosial dengan lingkungan baik di rumah, sekolah mapun dengan teman sebayanya. ${ }^{14}$

Interaksi sosial dapat memberikan konteks dimana anak-anak belajar untuk menyesuaikan diri dengan lingkungan sosial. Saat berinteraksi dengan orang tua anak-anak belajar aturan sosial seperti strategi pengambilan sosial dan negosiasi serta caracara untuk memecahkan kode isyarat emosional. ${ }^{15}$

\section{Hubungan pola asuh orang tua tunggal ibu dengan kematangan emosi anak pra sekolah usia 4-6 tahun}

Berdasarkan uji Chi-square didapat $p<0,05$. Hasil tersebut dapat disimpulkan bahwa ada hubungan yang signifikan pola asuh orang tua tunggal ibu dengan kematangan emosi anak. Pola asuh yang baik diterapkan dalam keluarga yaitu pola asuh demokratif, pola asuh ini akan membiasakan anak untuk mengemukakan pendapatnya sehingga ketika anak membutuhkan sesuatu, anak akan mengutarakannya kepada ibu, karena tipe ini membiasakan anak untuk berdiskusi dengan batasanbatasan tertentu.

Gaya pengasuhan membantu anak dalam mengembangkan kematangan emosi yang berperan dalam membentuk perilaku dan kepribadian. Biasanya seorang anak tampil tergantung dari gaya pengasuhan orang tua mereka, hubungan baik dengan orang tua cendrung terlihat pada saat penyesuaian sosial, penyesuaian emosional danefisiensi diri. ${ }^{16}$

Kematangan emosi anak, membuktikan bahwa gaya pengasuhan yang baik akan berdampak baik dalam perkembangan fisik, emosi, keselamatan dan kesejahteraan anak. Pengalaman emosional pada anak pertama kali terjadi di dalam keluarga, jadi gaya penagsuhan yang baik kemudian diterapkan dalam keluarga mempengaruhi perkembangan kematangan emosional anak. ${ }^{5}$

Anak yang dibesarkan dalam keluarga yang menerapkan pola asuh otoriter cendrung mangalami dan menunjukkan emosi negatif, seperti ketakutan, amarah, rasa bersalah dan kegugupan dibandingkan dengan anak yang dibesarkan dalam keluarga demokratif dan permisif. ${ }^{17}$

Anak dari orang tua yang otoriter umumnya cenderung menampilkan emosi yang terbatas atau emosional tidak fleksibel karena mereka diberikan sangat sedikit kesempatan untuk mengungkapkan pikiran dan perasaan mereka di rumah. Ketika mereka mengalami situasi yang tidak menguntungkan, anakanak dari keluarga pola asuh otoriter "shutdown," 
menjadi emosional ditarik, tabah, atau tenang, ini merupakan tanda rendah kecerdasan emosional. ${ }^{18}$

\section{Hubungan pola asuh orang tua tunggal ibu dengan keterampilan sosial anak pra sekolah usia 4-6 tahun}

Hasil uji Chi-square didapat $p<0.05$. Hasil tersebut dapat dismpulkan bahwa ada hubungan pola asuh orang tua tunggal ibu dengan keterampilan sosial anak pra sekolah usia 4-6 tahun. Pola asuh yang diterapkan oleh ibu dalam keluarga akan berdampak pada kebiasaan, keterampilan interaksi, dan kemandirian anak dalam keluarga.

Gaya pengasuhan ibu berhubungan dengan pengendalian diri dan keterampilan sosial anak, bahwa keterkaitan anak dengan ibu secara langsung maupun tidak langsung mempengaruhi perkembangan keterampilan sosial anak yang dipengaruhi dari efek gaya pengasuhan. Gaya pengasuhan yang hangat, berwibawa dan mendukung merupakan hal penting yang menghasilkan sikap mental yang positif, sedangkan gaya pengasuhan orang tua yang pengendali menghasilkan sikap mental yang negatif. Oleh karena itu gaya pengasuhan ibu dapat mempengaruhi perkembangan sosial anak. ${ }^{19}$

Pola asuh demokratis mempengaruh keterampilan sosial anak, terdapat hubungan yang positif dan signifikan antara gaya pengasuhan orang tua demokratif dengan keterampilan sosial anak. Hal ini dapat menunjukkan bahwa anak dari orang tua dengan pola asuh demokratif atau berwibawa akan menunjukkan perilaku prososial seperti kerja sama, ketenangan, empati dengan teman, sehingga membuat mereka dengan mudah diterima dalam lingkungan bermain atau sosial. ${ }^{20}$

\section{SIMPULAN}

Terdapat hubungan yang bermakna antara pola asuh orang tua tunggal ibu dengan kematangan emosi pada anak pra sekolah usia 4-6 tahun.

Terdapat hubungan yang bermakna antara pola asuh orang tua tunggal ibu dengan keterampilan sosial pada anak pra sekolah usia 4-6 tahun.

\section{SARAN}

Diharapkan kepada pendidik/guru PAUD untuk memberikan pengarahan kepada orang tua khususnya orang tua tunggal ibu untuk dapat menerapkan pola asuh demokratif sehingga nantinya anak memiliki kematangan emosi dan keterampilan sosial yang baik berkembang sesuai dengan usianya dan menciptakan suasana yang bermakna dalam proses pembelajaran.

\section{UCAPAN TERIMAKASIH}

Terimakasih dan penghargaan peneliti sampaiakan kepada Kepala Dinas Pendidikan Kota Padang, Kepala Sekolah dan ibu Guru TK/PAUD Kecamatan Koto Tangah Kota Pada yang telah memebrikan izin dalam penyelesaian penelitian ini.

\section{DAFTAR PUSTAKA}

1. Lansford JE. Parental divorce and children â€ $€^{\mathrm{TM}} \mathrm{S}$. Perspect Psychol Sci. 2017;4(2):140-52.

2. Fernandez AR, Alvarez DM, Woitschach $P$, Suarez AJ, Cuesta IM. Parental involvement and academic performance: less control and more communication = Implicacion familiar y rendimiento academico: Menos control y mas comunicación. Psicothema. 2017;29(4):453-61.

3. Khasanah K. Pengaruh pola asuh ibu sebagai single parent dalam peningkatan pembinaan karakter religi motivasi nilai belajar anak di $\mathrm{MI} A \mathrm{~L}$ Khoiriyah Wonolelo Pleret Bantul Yogyakarta [tesis]. Yogyakarta: Program Studi Magister Pendidikan Universitas Islam Negeri Sunan Kalijaga; 2016.

4. Rahman HA. Pola pengasuhan anak yang dilakukan oleh single mother. Jurnal IImiah Pendidikan Sosial Antropologi. 2014;4(1) .

5. Jisha KV. A Study on the relationship of parenting style with emotional maturity of secondary school students. International J Indian Psychol. 2016; 3 (3):21-6

6. Mahabbati A, Purwandari $\mathrm{P}$, Suharmini $\mathrm{T}$, Praptiningrum N. Social skill scale based on diversity awareness for elementary school students: validity and reliability. Proceeding of the 
International Conference on Special and Inclusive Education (Icsie 2018):438-44.

7. Lacey RE. Understanding 21st century relationships: a compendium of key data. 2012;(July 2012). (diunduh 28 Oktober 2018): Tersedia dari: http://www.oneplusone.org. uk/content item/understanding-21st-centuryrelationships-a-compendium-of-key-data/

8. Meier A, Musick K, Flood S, Dunifon R. Mothering experiences: how single-parenthood and employment shift the valence. Demography. 2017;53(3):649-74.

9. The Departement Of Economic And Social Affairs Of the United Nations. United Nations Demograhic Yearbook: United Nations Publication. America Serikat. 2014. (diunduh 30 Oktober 2018). Tersedia dari: https://www.un.org/en/development/ desa/news/2014.html

10. Badan Pusat Statistik Kota Padang. Kota Padang dalam Angka. Padang. BPS Kota Padang. 2017. hlm. 171

11. Greenwood B. The Baumrind theory of parenting styles. Global Post International News. Retrieved December 15, 2013. (diunduh 1 November 2018). Tersedia dari: http://everyday.globalpost.com/ baumrind theory parenting styles 6147.html

12. Winter L, Morawska A, Sanders M. The knowledge of effective parenting scale (KEPS): a tool for public health approaches to universal parenting programs. J Prim Prev. 2012;33(2-3):85-97.

13. King LA. Psikologi umum: sebuah pandangan apresiasif. Edisi ke-2. Marwensdy B, penterjemah. Jakarat: Salemba Humanika. 2010.hlm. 85-6.

14. Lestiawati IM. Pengaruh pola asuh orang tua terhadap kemampuan sosial anak usia 6-7 tahun. Jiv. 2013;8(2):111-9.

15. Haven EL, Manangan CN, Sparrow JK, Wilson BJ. The relation of parent-child interaction qualities to social skills in children with and without autism spectrum disorders. Autism. 2014;18(3):292-300.

16. Alegre $A$. The relation between the time mothers and children spent together and the children's trait emotional intelligence. Child Youth Care Forum. 2012;41(5):493-508.

17. Farrell G. The relationship between parenting style and the level of emotional intelligence in preschoolaged children. PCOM Psychol Diss 2015 (diunduh 30 Juni 2019). Tersedia dari: http://digitalcommons. pcom.edu/psychology dissertations

18. Williams LQ. The 4 types of parenting styles. RThe Washington; 2016 April 20 (diunduh 19 Juni 2019). Tersedia dari: http://lqwilliams2.hubpages. com/hub/The-3-Types-of-Parenting-Styles.

19. Hosokawa R, Katsura T, Shizawa M. Relations of mother's sense of coherence and childrearing style with child's social skills in preschoolers. Child Adolesc Psychiatry Ment Health. BioMed Central; 2017;11(1):1-11.

20. Mensah MK, Kuranchie A. Influence of parenting styles on the social development of children. Acad J Interdiscip Stud. 2013;2(3):123-30. 